\title{
Impact Factors Workgroup Report
}

Surie Allard, Ali Andalibi, Patty Baskin, Marilyn Billings, Eric Brown, Todd Carpenter, Stephanie Orfano, Brian Selzer

\section{Abstract / Workgroup Question}

Following up on recommendations from OSI 2016, this team will dig deeper into the question of developing and recommending new tools to repair or replace the journal impact factor (and/or how it is used), and propose actions the OSI community can take between now and the next meeting. What's needed? What change is realistic and how will we get there from here?

\section{Introduction}

The Impact Factors workgroup (IFW17) convened at the second meeting of the Open Scholarship Initiative (OSI) in Washington DC, USA, on April 18-21, 2017. Membership of the group was selfselected, although multiple stakeholders and viewpoints were represented within the discussion, including representatives from libraries, university administration, publishers, and not-for-profit institutions. Refer to the names and affiliations of this workgroup's members included at the end of this report.

\section{Perspective Summary}

Membership from the OSI 2016 Impact Factors workgroup did not carry over to 2017, although several members had attended the previous year's conference as members of other workgroups. Membership included multiple stakeholders and viewpoints, with representatives from libraries, university administration, publishers, and not-for-profit institutions. Members were knowledgeable about open and how the Journal Impact Factor (JIF) is inadequate in terms of measuring impact.

\section{Areas of Agreement and}

\section{Disagreement}

The Impact Factors Workgroup report produced at OSI 2016 (http://dx.doi.org/10.13021/G88304) was used as a foundation for our activities. Members agreed that they would use the six points of consensus from "The Journal Impact Factor and its discontents: steps toward responsible metrics and better research assessment" (2016) to dig deeper into some of the core issues surrounding impact and how it is assessed.

The following four issues were identified:

- Scholarly communication impact encompasses more than just articles and monographs. This is consistent with OSI's overall focus of 2017 and with the IFWG work from 2016. While the 2016 action plan focused primarily on journal articles, the background section noted: "...open scholarship is about more 
than just $\mathrm{OA}$, it also includes sharing research data, methods and software, the pre-registration of protocols and clinical trials, better sharing of the outcomes of all research including replication studies and studies with negative results, and early sharing of information about research outcomes." IFW17 feels this is an essential construct as impact factor work moves forward.

- Multiple metrics should be used as appropriate within the discipline to represent the breadth of the discipline and to encourage new ideas. Impact factors should be applicable to the wide variety of disciplines that create knowledge, including creative achievements such as films, art, and music. In order to recognize the paradigmatic diversity represented both within and across disciplines, there is a need for more than one approach (and metric) to represent impact. Depending on one metric can have an inhibiting factor on the success of new journals, particularly those that are $\mathrm{OA}$, and can limit the potential venues for new ideas and widespread dissemination of results. Measuring impact factor with alternative means could create fresh impetus for OA uptake and other ways for funders to support OA.

- Diversity and inclusion is important when considering scholarly impact. We are referring to intellectual diversity in all its dimensions, and we champion the need for recognition of scholarship across disciplines and across institutions. We recognize also that governance and business sustainability have in- fluence in terms of OA uptake and that impact factors are often used for decision-making during governance and sustainability practices.

- There continues to be a need to transform and modernize the research evaluation process. The 2016 report noted: “There is both a perception and a reality that such processes (tenure and promotion) are influenced by the JIF, and so researchers who are subject to those processes understandably adjust their publishing behavior based on the JIF." The tenure and promotion $(\mathrm{T} \& \mathrm{P})$ process influences how we can identify and what we can promote as an impact factor alternative measurement.

The group was unable to come up with a united plan of action involving all stakeholders acting together. Rather, a list of action items for 2018 was presented, which calls for some stakeholder groups to work together.

In review of reports from other 2016 workgroups to glean what output may be pertinent to our activities, the group adopted the stakeholder definitions presented by the OSI 2016 Who Decides? workgroup (http://dx.doi.org/10.13021/G8P30V):

- Funding agencies, including, for example, government and nongovernment entities, have the power to allocate resources and the power to define policies.

- Libraries have spending power, as those who procure information resources, as well as the power of choice- that is, the ability to choose what to invest in. 
- Universities have the power to make policies and the power to allocate their resources.

- Publishers, including learned societies, have the power emanating from their ownership of journals and the related publishing infrastructure.

- Researchers, of course, have the power to choose what and where to publish.

\section{Next Steps for OSI 2018}

The OSI 2016 Impact Factors report included an action plan which identified four intended changes and some specific actions to facilitate these changes. We discussed each of the four items to determine if the identified actions had been taken and, if so, were they effective. We then reviewed the current situation of the intended change, and determined the best strategy to move forward given our level of time and resources. What follows are four products we identified as helping to move the mission forward. For each product, we identified specific and discrete action items, the priority of the action item and some activities for implementation. What remains to be done is for individuals to adopt an action item and guide activities to completion. We recommend that 2018 meeting participants review this product list and determine which action items may still need to be tackled and completed during the meeting.

\section{Product 1. Follow-up on workgroup report discussions}

\begin{tabular}{l|l|l|}
$\begin{array}{l}\text { Action Item } \\
1.1 \text { Examine the exceptions out- } \\
\text { lined in report where JIF did not } \\
\text { impede the uptake of open practic- } \\
\text { es (eLife, PLOS, Nucleic Acids Re- } \\
\text { search) }\end{array}$ & $\begin{array}{l}\text { Activities } \\
\text { Open up dialogue with } \\
\text { journal editors: what's } \\
\text { working / what's not / } \\
\text { what's missing? }\end{array}$ \\
$\begin{array}{l}\text { 1.2 Update initiatives that take a } \\
\text { more transparent approach to } \\
\text { scholarship (Crossref Event Data } \\
\text { service, Initiative for Open Cita- } \\
\text { tions etc.) }\end{array}$ & Moderately High & $\begin{array}{l}\text { Major output: Interview } \\
\text { protocol and list of con- } \\
\text { tacts }\end{array}$ \\
\hline
\end{tabular}

\section{Product 2. Help facilitate implementation of DORA recommendations}

As described on their website (http://www.ascb.org/dora/), "The San Francisco Declaration on Research Assessment (DORA), initiated by the American Society for Cell Biology (ASCB) together with a group of editors and publishers of scholarly journals, recognizes the need to improve the ways in which the outputs of scientific research are evaluated."

As of April 26, 2017, Nature Journals publicly announced their support of DORA, however, there are publishers who do not support this declaration in its entirety. While this report has a focus on DORA, other frameworks that express the same sentiments should be considered within this process as well. 


\begin{tabular}{|c|c|c|}
\hline Action Item & Priority Level & Activities \\
\hline $\begin{array}{l}2.1 \text { Develop landscape analysis } \\
\text { from an environmental scan to bet- } \\
\text { ter understand DORA committed } \\
\text { organizations and their relationship } \\
\text { to pertinent funding agencies. Use } \\
\text { this environmental scan as an op- } \\
\text { portunity to explore if other frame- } \\
\text { works exist or if they are in devel- } \\
\text { opment }\end{array}$ & Moderately High & $\begin{array}{l}\text { - Use list of DORA organi- } \\
\text { zations and arrange by } \\
\text { characteristics } \\
\text { - At OSI: talk to partici- } \\
\text { pants to identify inroads } \\
\text { available }\end{array}$ \\
\hline $\begin{array}{l}2.2 \text { Build resources (elevator pitch) } \\
\text { that provide talking points on ways } \\
\text { to improve the evaluation of re- } \\
\text { search. To be shared with identified } \\
\text { stakeholders. Use as an opportunity } \\
\text { to discuss implementation solutions } \\
\text { and roadblocks }\end{array}$ & High & $\begin{array}{l}\text { - Use stakeholder groups } \\
\text { identified in the 'What is } \\
\text { Open' } 2016 \text { workgroup to } \\
\text { start writing material } \\
\text { - DORA website as major } \\
\text { resource. }\end{array}$ \\
\hline
\end{tabular}

Product 3. Support disciplinary ownership of assessment

\begin{tabular}{|l|l|l|}
\hline $\begin{array}{l}\text { Action Item } \\
\begin{array}{l}3.1 \text { Identify guidelines for DORA } \\
\text { inspired tenure and promotion } \\
\text { frameworks }\end{array}\end{array}$ & $\begin{array}{l}\text { Medium } \\
\text { Activities }\end{array}$ & $\begin{array}{l}\text { Design template based on } \\
\text { guidelines }\end{array}$ \\
& $\begin{array}{l}\text { Identify organizations to } \\
\text { volunteer to pilot this ap- } \\
\text { proach and bring back } \\
\text { next year for greater buy- } \\
\text { in }\end{array}$ \\
$\begin{array}{l}3.2 \text { Enlist learned societies to help } \\
\text { educate through events at profes- } \\
\text { sional meetings }\end{array}$ & Moderately High & $\begin{array}{l}\text { How: outreach through } \\
\text { COAPI }\end{array}$ \\
& $\begin{array}{l}\text { Design a template for } \\
\text { panel content and suggest } \\
\text { potential speakers } \\
\text { Use the Tiger Team ap- } \\
\text { proach: Where do we } \\
\text { have contacts so that we } \\
\text { can get on the agenda }\end{array}$ \\
\hline
\end{tabular}


Product 4. Share information about JIF, metrics, their use and misuse

\begin{tabular}{|c|c|c|}
\hline Action Item & Priority Level & Activities \\
\hline $\begin{array}{l}\text { 4.1 Create and populate an infor- } \\
\text { mation page containing metrics that } \\
\text { are available and gaining foothold }\end{array}$ & High & $\begin{array}{l}\text { Communicate with Met- } \\
\text { rics Toolkit developers, } \\
\text { with goal to collaborate } \\
\text { after rollout at Force11 } \\
\text { (Berlin, Oct 2017) } \\
\text { - Identify and facilitate col- } \\
\text { laboration amongst stake- } \\
\text { holders to drive innova- } \\
\text { tion and solutions for ag- } \\
\text { gregation of metrics data }\end{array}$ \\
\hline
\end{tabular}

\section{Answering the Implementation}

Challenges Identified at OSI 2016

The OSI 2016 Impact Factor report identified three major challenges for moving ahead with impact factor activities within OSI. Our group provides strategies for addressing these in a realistic and collaborative way, however, they remain obstacles moving forward:

- How to continue to engage the OSI participants in this activity?

○ IFW17 has identified actionable plans. At this point, individuals can adopt an action item to guide activities to completion.

- We recommend ensuring continuity by having at least one member from current workgroup at the 2018 workgroup meeting

- What channels and methods should be used to effectively extend the participation to represent fully all stakeholders from around the world?

- IFW17 identified the need for collaborations as evidenced by Metrics Toolkit (Force11: https://www.force11.org/tools)

- Given limited resources, how should the work that we have proposed be prioritized?

○ IFW17 has created "work packets" that are clearly defined and which have been assigned priority levels 


\section{Impact Factors Workgroup}

Suzie Allard, Associate Dean for Research and Director, Center for Information \& Communication Studies, University of Tennessee

Ali Andalibi, Associate Dean of Research, Science, George Mason University

Patty Baskin, President, Council of Science Editors (CSE) and Executive Editor, Neurology Journals

Marilyn Billings, Scholarly Communication \& Special Initiatives Librarian, UMass Amherst Eric Brown, Division Leader, Explosive Science and Shock Physics, Los Alamos National Laboratory

Todd Carpenter, Executive Director, NISO

Stephanie Orfano, Head of Scholarly Communications, University of Toronto

Brian Selzer, Assistant Director of Publications, American Public Health Association 